\title{
Pemanfaatan Terapi Musik sebagai Pengobatan Alternatif Korban Penyalahgunaaan Narkoba di Panti Rehabilitasi Mutiara Abadi Binjai
}

\author{
Junita Batubara ${ }^{1}$, Juliaster Marbun ${ }^{2}$, Hendro T.G Samosir ${ }^{3}$, Kamaluddin Galingging ${ }^{4}$ \\ Universitas HKBP Nommensen Medan \\ Jln. Sutomo No. 4A Medan \\ nitabtbara72@gmail.com¹, juliaster.marbun@uhn.ac.id², hendro.samosir@uhn.ac.id ${ }^{3}$, \\ kamaluddinsigalingging@uhn.ac.id ${ }^{4}$
}

\begin{abstract}
This research was conducted with the aim of helping patients undergoing rehabilitation who previously used drugs as a treatment. Music therapy is a universal therapy and can be accepted by everyone because we don't need heavy brain work to interpret music. Music therapy is very easily accepted by our auditory organs and then through the auditory nerve it is channeled to the brain, namely the limbic system which has a relationship in emotional behavior. In this research, music therapy used is passive music therapy, the reason for choosing passive music therapy is because music therapy is cheap, easy and effective. The patient only needs to listen and appreciate a certain strain of music that is adapted to the problem, where the music therapy can reduce pain, make the body and mind more relaxed and other benefits are adjusted to the content of the music. The most important thing in passive music therapy is that the selection of the type of music must be appropriate to the patient's needs. The results of the research show that listening to music can be a solution to help patients who are in rehabilitation recover so that these patients can move and have the confidence to return to their activities and can be accepted by society as usual.
\end{abstract}

Keywords: music, therapy, drugs, rehabilitation

\begin{abstract}
ABSTRAK
Penelitian ini dilakukan dengan tujuan untuk membantu pasien yang sedang menjalani rehabilitasi yang sebelumnya menggunakan narkoba sebagai salah satu pengobatan. Terapi musik menjadi terapi yang universal dan bisa diterima oleh semua orang karena kita tidak membutuhkan kerja otak yang berat untuk menginterpretasi alunan musik. Terapi musik sangat mudah diterima organ pendengaran kita dan kemudian melalui saraf pendengaran disalurkan kebagian otak yaitu sistem limbic yang mempunyai hubungan dalam perilaku emosional. Pada penelitian ini, terapi musik yang dilakukan adalah terapi musik pasif, alasan pemilihan terapi musik pasif karena terapi musik menjadi lebuh murah, mudah, dan efektif. Pasien tinggal mendengarkan dan menghayati suatu alunan musik tertentu yang disesuaikan dengan masalahnya, di mana terapi musik tersebut dapat mengurangi rasa sakit, membuat fisik dan pikiran menjadi lebih rileks serta manfaat lain disesuaikan dengan muatan isi musiknya. Hal terpenting dalam terapi musik pasif adalah pemilihan jenis musik harus tepat dengan kebutuhan pasien. Hasil penelitan menunjukkan bahwa mendengar musik bisa menjadi salah satu solusi untuk membantu pasien yang sedang rehabilitasi bisa pulih sehingga para pasien ini bisa beraktivitas dan memiliki percaya diri untuk kembali melakukan kegiatannya dan dapat diterima masyarakat seperti biasanya.
\end{abstract}

Kata kunci: musik, terapi, narkoba, rehabilitasi 


\section{PENDAHULUAN}

Permasalahan narkotika telah membuat seluruh negara di dunia khawatir dan resah. United Nations Office on Drugs and Crime (UNODC) sebagai Badan dunia yang mengurusi masalah narkotika mencatat setidaknya ada 271 juta jiwa di seluruh dunia atau 5,5\% dari jumlah populasi global penduduk dunia dengan rentang usia antara 15 sampai 64 tahun telah mengonsumsi narkoba, setidaknya orang tersebut pernah mengkonsumsi narkotika (UNODC, 2019). Sementara itu, Badan Narkotika Nasional (BNN) mencatat bahwa persoalan narkotika di Indonesia masih dalam kondisi yang memerlukan perhatian dan kewaspadaan tinggi secara terus menerus dari seluruh elemen bangsa Indonesia (BNN, 2019).

Jika kondisi ini dibiarkan maka akan membuat generasi muda di Indonesia ini menjadi hancur. Sebagai salah satu Negara dengan penduduk terbesar di dunia, Indonesia sudah berada ditahap menghawatirkan akibat penduduknya banyak yang mengkonsumsi atau menyalahgunakan narkoba. Adapun tindak lanjut pemerintah melalui BNN melakukan berbagai cara untuk menyembuhkan bahkan memerangi penggunaan narkoba yang kian hari semakin meningkat. Berbagai macam cara mereka lakukan untuk mendapatkan kesembuhan, akan tetapi ada juga yang tidak ingin sama sekali terlepas dari narkoba malahan menikmati candunya itu pada narkoba. Salah satu cara yang dilakukan untuk penyembuhan pengguna narkoba adalah dengan cara Rehabilitasi.

\section{Pemerintah melalui BNN (Badan}

Narkotika Nasional) melakukan tindakan melalui terapi rehabilitasi secara ketat dan sistematik dengan menggunakan metode terapi medis dan psikologis, maupun komunitas-komunitas atau organisasi sukarela lainnya yang ingin membantu para pecandu terlepas dari jeratan narkoba (Zakiyah Fatmiludya, 2018). Rehabilitasi bertujuan untuk mewujudkan kepulihan dari ketergantungannarkotika dan mengembalikan keberfungsian sosial pecandu dan korban penyalahgunaan narkotika di masyarakat. Dalam rangka memenuhi kebutuhan masyarakat akan rehabilitasi pecandu dan korban penyalahgunaan narkotika (BNN, 2019). Oleh karena tidak selamanya berbagai macam penyakit dapat disembuhkan dengan obat medis atau kecanggihan perangkat medis. Begitupun pecandu narkoba, mereka tidak selamanya dapat dipulihkan hanya melalui obat medis atau perangkat medis saja (Solihin, 2004).

Salah satu lembaga yang melakukan rehabiltasi yaitu Yayasan Rehabilitasi Narkoba Mutiara Abadi Binjai (MAB). Lembaga yang didirikan pada tahun 2016, lembaga ini didirikan sebagai upaya untuk mendukung pemerintah dalam mengatasi permasalahan para pengguna narkoba yang ingin lepas dari jeratan ketergantungan penggunaan narkoba yang selama ini mereka konsumsi sehingga menyebabkan hal fatal bahkan kematian. Di lembaga ini pasien yang sedang menjalani rehabilitasi dilayani dengan baik dengan tujuan untuk memulihkan kondisi mental maupun kejiwaan sehingga nantinya ketika sudah pulih bisa beraktivitas dan bergabung dengan masyarakat tanpa ada sekat. 
Menurut Holt \& Kaiser dalam Yuri Christiani dkk (2021: 110) mengatakan bahwa karya seni dapat menjadi wadah atau tempat untuk mengeksplorasi emosi, pikiran, persepsi, keyakinan dan pengalaman dengan seni yang berfungsi sebagai wujud nyata dengan maksud tujuan memberi umpan balik atau sebuah jalan. Terapi seni menggunakan media bunyi-bunyian yang disusun dalam rangkaian melodi dan diproses menjadi sebuah karya komposisi musik merupakan salah satu alternatip terapi atau treatment bagi orang-orang yang sedang dalam rehabilitasi pengguna Narkoba.

Berdasarkan observasi di lapangan tim peneliti melakukan berbagai kajian dan melakukan wawancara kepada pengurus yayasan yang diwakili oleh Eben Ezer Manullang dan pasien yang sedang menjalani rehabilitasi. Kondisi dilapangan ditemukan berbagai usia pasien tahap rehabilitasi yang mana pada masa lalu mereka menggunakan berbagai macam jenis narkoba. Adapun tindakan penyembuhan yang kami lakukan adalah melalui terapi musik.

World Federation of Music Therapy menjelaskan terapi musik sebagai penggunaan profesional dari musik dan elemennya sebagai salah satu intervensi dalam bidang kesehatan, pendidikan, dan lingkungan sehari-hari dengan individu, kelompok, keluarga, atau komunitas yang mencoba untuk melakukan optimalisasi kualitas hidupnya dan meningkatkan kesehatan fisik, sosial, komunikatif, emosional, intelektual, spiritualnya serta kondisi well-being dirinya (Edwards, 2017).

Adajuga pendapat lain yang menyatakan bahwa terapi musik merupakan intervensi keperawatan, di mana musik dijadikan sebagai media untuk aktivitas terapeutik dengan tujuan untuk memelihara, memperbaiki serta pengembangan kesehatan mental, kesehatan fisik, dan kesehatan emosi (Padila et al., 2020). Musik memiliki kekuatan untuk mengobati penyakit dan meningkatkan kemampuan pikiran seseorang. Musik diterapkan menjadi sebuah terapi dan musik dapat meningkatkan, memulihkan, memelihara kesehatan fisik, mental, emosional, sosial dan spiritual. Hal ini disebabkan musik memiliki beberapa kelebihan, yaitu karena musik bersifat nyaman, menenangkan, menimbulkan perasaan positif, membuat rileks, berstruktur, dan universal.

Terapi musik menjadi terapi yang universal dan bisa diterima oleh semua orang karena kita tidak membutuhkan kerja otak yang berat untuk menginterpretasi alunan musik. Terapi musik sangat mudah diterima organ pendengaran kita dan kemudian melalui saraf pendengaran disalurkan kebagian otak yaitu sistem limbic yang mempunyai hubungan dalam perilaku emosional (Puspaningrum et al, 2015). Selain itu alunan musik mampu menstimulus tubuh untuk menciptakan molekul Nitrit oxide (NO) yang bekerja di tonus pembuluh darah sehingga mengurangi kecemasan. Kesamaan antara respon yang harmonis dalam tubuh dan irama musik akan menyesuaikan ritme atau irama tubuh sehingga timbul kesan yang menyenangkan dan membahagiakan (Saifudin \& Wijaya, 2016).

Hasil riset mengenai musik khususnya musik kontemporer menunjukan bahwa musik dapat mengharmoniskan dan 
menyeimbangkan semua irama dari badan kita, termasuk denyut jantung, kecepatan bernafas, tekanan darah, frekuensi gelombang otak, dan kecepatan respikatori primer. Lewat pengaruhnya bermanfaat pada kekebalan tubuh dan hormonal (Louise Montello, 2004).

Pada penelitiannya sebelumnya, Terapi musik telah terbukti memainkan peran penting dalam membantu mengatasi gejala fisik dan tekanan psikologis (Fallek et al., 2019). Musik Terapi dapat menimbulkan rasa senang, kondisi rileks, mengurangi kadar kortisol dan menurunkan tingkat stress (Van der Steen, et al, 2018). Terapi musik merupakan suatu proses yang memadukan antara aspek penyembuhan musik itu sendiri dengan kondisi fisik/tubuh, emosi, mental, spiritual, kognitif dan situasi kebutuhan sosial seseorang. Terapi musik merupakan terapi atau metode penyembuhan dengan musik melalui energi yang dihasilkan dari musik itu sendiri (Natalina, 2013). Musik juga menyediakan media relaksasi dengan komunikasi lewat ritme, mendengarkan musik, isyarat non-verbal, eksplorasi, gerakan, dan improvisasi (Torres ML, et al, 2016).

Kalangan kedokteran Amerika bereksperimen dengan pemanfaatan musik guna penyembuhan sepanjang abad kesembilan belas dan awal abad keduapuluh, Hanya saja metode tersebut masih jarang dilakukan di Indonesia. Terutama sekali kesadaran miring masyarakat di dalam memandang ihwal musik. Akibatnya, musik yang pada awalnya bersifat luhur dan ruhaniyah, pada akhirnya lebih banyak disadari sebagai sesuatu yang negatif. Hal ini disepakati pula oleh Jessica salah satu mahasiswa kedokteran di salah satu universitas di Indonesia yang saat ini magang di rumah sakit Florida, Amerika Serikat sebagai Music Therapist bahwasanya di Indonesia sendiri masih jarang yang melakukan penyembuhan atau pengobatan menggunakan terapi musik. Dimana musik biasanya digunkan hanya sebagai hiburan, tapi dalam hal ini digunakan untuk melakukan pengobatan. Selain itu, kalangan dokter di Indonesia juga masih merasa asing dengan adanya pengobatan menggunakan musik (Idntimes, 2019).

Komposisi untuk menyediakan musik yang cocok digunakan dalam sesi terapi, diperlukan pemahaman lebih lanjut dari latar belakang pembuatan musik, terutama pesan emosi apa yang akan disampaikan dalam musik, karena dikhawatirkan pesan yang ditangkap oleh pendengar berbeda dengan pesan sesungguhnya yang dituangkan penulis dalam musiknya karena ada peran kultur (Argstatter, 2016).

Pada penelitian ini, Terapi musik yang dilakukan adalah terapi musik pasif, alasan pemilihan terapi musik pasif karena terapi musik yang murah, mudah dan efektif. Pasien tinggal mendengarkan dan menghayati suatu alunan musik tertentu yang disesuaikan dengan masalahnya, dimana terapi musik tersebut dapat mengurangi rasa sakit, membuat fisik dan pikiran menjadi lebih rileks serta manfaat lain disesuaikan dengan muatan isi musiknya. Hal terpenting dalam terapi musik pasif adalah pemilihan jenis musik harus tepat dengan kebutuhan pasien. Adapun jenis musik yang digunakan dalam terapi adalah musik instrumental dimana musik tersebut terbagi atas dua gaya musik: 1) Rhythm of Birds (Karya Junita Batubara) 


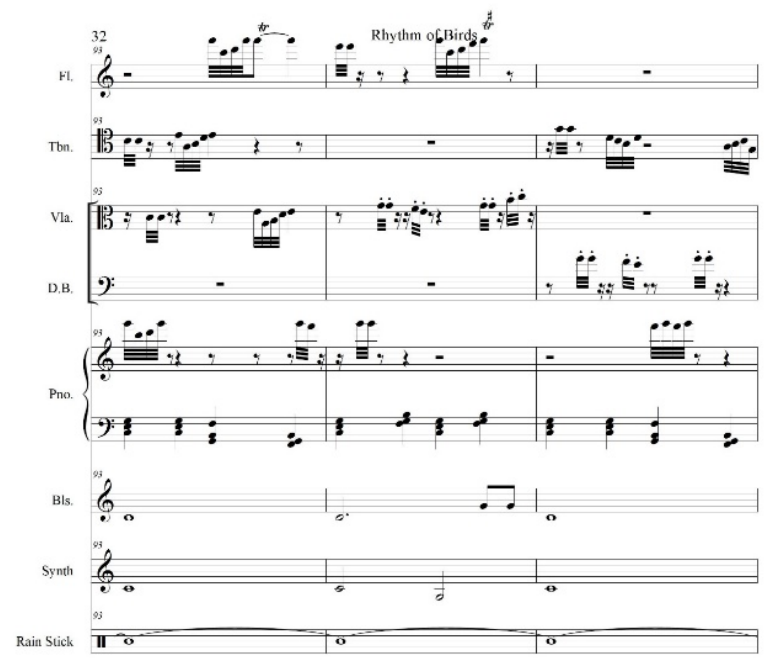

Gambar 1. Skor musik bagian bar 32-34 Rhythm of Birds karya Junita Batubara

dan 2) Fiesta Loca (Karya Kenny G). Untuk bagian artikel yang akan dibahas adalah musik terapi yang menggunakan musik instrumental Rhythm of Birds. Pemilihan musik ini berdasarkan hasil analisa komposer dimana suara alam mampu membawa suasana ketenangan hati. Komposer dalam hal ini menciptakan musik instrumental yang berjudul Rhythm of Birds dimana idenya adalah berasal dari suara-suara burung dipagi hari. Suara-suara tersebut direkam saat suasana pagi hari pukul 06.00wib. Kemudian rekaman ini diaplikasikan ke dalam skor musik dengan menggunakan instrumen musik seperti Flute, trombon, Viola, Double bass, Piano, Bells, Synthesizer, dan Rain Stick. Secara skor musik maka dapat dilihat pada gambar 1 .

Di atas adalah bentuk 'mentah' dimana bentuk tersebut dibuat kembali dalam bentuk waveform dengan menggunakan program Cubase sehingga hasilannya merupakan gabungan suara alam, suara burung dan instrumen musik digital. Tujuan dari perekaman ini dalam bentuk musik digital adalah lebih memudahkan peneliti dalam melakukan observasi antara musik instrumental dengan orang yang diobservasi. Irama musik Rhythm of Birds adalah polyritem dimana musiknya memiliki pola ritem yang berbeda sehingga memungkinkan untuk pendengar merasakan suasana yang membawa ketenangan dan menikmati suasana tersebut dengan tubuh yang rileks. Penelitian ini diharapkan menjadi salah satu solusi untuk membantu pasien yang sedang rehabilitasi bisa pulih sehingga para pasien ini bisa beraktivitas seperti biasanya.

Metode yang digunakan di dalam penelitian adalah metode deskriptif analitik dengan pendekatan kualitatif, Metodologi kualitatif sebagai prosedur penelitian yang menghasilkan data deskriptif berupa katakata tertulis atau lisan dari orang-orang dan perilaku yang dapat diamati (Moleong, 2001: 9) dengan menyajikan rangkuman hasil survei dan wawancara yang berupa kuisioner.

Manusia sebagai instrument sebagaimana yang diungkapkan oleh Guba dan Lincoln 1981, manusia sebagai instrument mencakup segi responsif, dapat menyesuaikan diri, menekankan keutuhan, mendasarkan diri atas perluasan pengetahuan, memproses data secepatnya, memanfaatkan kesempatan untuk mengklarifikasikan dan mengikhtisarkan dan mencari respon yang tidak lazim dan idiosinkritik. Adapun sampel yang kami lakukan adalah pasien yang sedang menjalani rehabilitasi di Yayasan Mutiara Abadi Binjai (MAB) pada usia 27-51 tahun sebanyak 8 orang responden. Sebelum kami melakukan wawancara dengan pasien dan melihat reaksi mereke ketika mendengar musik instrumental yang kami lakukan terlebih dahulu meminta 
persetujuan dari pengurus yayasan. Yang menjadi fokus kami lihat adalah respon terhadap musik melalui gerakan tubuh ketika mendegarkan musik dengan tempo cepat maupun tempo lambat.

Nama-nama pasien dalam penelitian ini menggunakan nama samaran, untuk menjaga etika dan nama baik pasien yang diangkat dijadikan sampling dalam penelitian untuk diberikan terapi melalui musik.

\section{METODE}

Metode yang diterapkan menggunakan Participation Action Reseach (PAR). Metode PAR menurut Norman K. Denzin (2009, hlm 424-428) terdiri atas tiga kata yang membentuk daur (siklus) dan saling berkaitan satu dengan yang lainnya yakni partisipasi, riset, dan aksi. Partisipasi merupakan bentuk sikap kepedulian untuk menghidupkan kembali tari Yudawiyata yang sudah punah, melalui rekonstruksi. Bentuk kepedulian tersebut dilatarbelakangi dengan adanya riset yang dilakukan sebelumnya. Kemudian aksi merupakan bentuk aktivitas dalam melakukan revitalisasi. Aktivitas ini mengarah pada tatanan rekonstruksi dan implementasi tari perang wayang gaya Sumedang.

Realisasi dari aktivitas tersebut dibagi menjadi beberapa tahapan yakni nyantrik, penguasaan hasil penyadapan, rekonstruksi, penerapan hasil rekonstruksi kepada penari, latihan gabungan dengan pangrawit menggunakan iringan gamelan, rekaman audio, rekaman visual, upload video ke kanal youtube, implementasi kepada masyarakat di Padepokan Sekar Pusaka, dan evaluasi.
Untuk menggali kembali tarian ini membutuhkan setidaknya nara sumber sekunder yang sempat mengetahui wujud dari objek tersebut. Oleh kareana itu, penelitian ini menggunakan pendekatan interpretasi untuk mengeksplanasi pengalaman yang dijelaskan nara sumber.

\section{HASIL DAN PEMBAHASAN}

Berdasarkan data dari tabel tersebut, menunjukkan pasien yang sedang menjalani rehabilitasi Yayasan Mutiara Abadi Binjai dengan berbagai usia dan juga jenis narkoba yang pernah digunakan. Para pasien tersebut sedang menjalani proses rehabilitasi untuk memulihkan kondisi agar bisa pulih dan bergabung bersama keluarga maupun bisa bergaul dengan masyarakat serta mereka tidak merasa terkucilkan.

Sebagai tindakan yang kami lakukan adalah dengan menggunakan dua tahap. Tahap pertama yang kami lakukan yaitu dengan melakukan wawancara terhadap para pasien dengan terlebih dahulu meminta pesertujuan dari kepada pengurus yayasan agar menginzinkan pasien yang rehabilitasi bisa kami wawancarai dan melihat respon terhadap musik melalui gerkan positif dengan melihat gerakan-gerakan tubuh (fisiologis). Tubuh sebagai media pengungkap perasaan, pikiran, dan imajinasi; pengungkap bahasa verbal dan nonverbal; media ungkap gerak nonverbal dan kecerdasan otot, berjalan sebagai fenomena metaforik-figural; serta sebagai hubungan antara tubuh-gerak-kulturzaman (Rustiyanti, 2015, hlm. 91).

Hasil wawancara dengan pasien yang 
Tabel 1. Data Pasien yang Sedang Menjalani Rehebilitasi Narkoba di Yayasan Mutiara Abadi Binjai (Sumber: Junita Batubara, 2021)

\begin{tabular}{cccccc}
\hline No & $\begin{array}{c}\text { Nama } \\
\text { Pasien }\end{array}$ & $\begin{array}{c}\text { Usia } \\
\text { (Th) }\end{array}$ & $\begin{array}{c}\text { Jenis } \\
\text { Kelamin }\end{array}$ & $\begin{array}{c}\text { Lama Mengikuti } \\
\text { Rehabilitasi }\end{array}$ & $\begin{array}{c}\text { Jenis Narkoba Yang Pernah } \\
\text { Dipakai }\end{array}$ \\
\hline 1 & NG & 44 & Laki-laki & 1 bulan & $\begin{array}{c}\text { Shabu-Shabu Setiap Harinya } \\
\text { Sebelum Direhab }\end{array}$ \\
\hline 2 & AM & 31 & Laki-laki & 2 tahun & Shabu-Shabu Dan Ekstasi \\
\hline 3 & IR & 41 & Laki-laki & 7 Bulan & Shabu-Shabu Dan Ganja \\
\hline 4 & RB & 27 & Laki-laki & 8 bulan & Shabu-Shabu \\
\hline 5 & LS & 42 & Laki-laki & 3 bulan & Shabu-Shabu \\
\hline 6 & Har & 51 & Laki-laki & 8 bulan & Ganja \\
\hline 7 & AH & 47 & Laki-laki & 2 bulan & Shabu-Shabu \\
\hline 8 & HA & 41 & Laki-laki & 1 tahun & Shabu-Shabu Dan Ganja \\
\hline
\end{tabular}

menjadi korban penyalahgunaan Narkoba terungkap bahwa mereka pada masa lalunya menggunakan narkoba disebabkan oleh beberapa hal, seperti depresi akibat masalah keluarga, tekanan pekerjaan, baik salah pergaulan maupun rasa penasaran dengan narkoba, sehingga mereka dengan nekat mengkonsumsi narkoba semata-mata untuk menenangkan pikiran mereka. Akibat dari perbuatan mereka yang menggunaka narkoba ini menyebabkan rusaknya fisik dan mental mereka. Sebagai upaya penyembuhan dari ketergantungan pihak keluarga melakukan tindakan rehabilitasi dengan datang ke lembaga untuk mendapatkan rehabilitasi, karena mereka ingin sembuh dan betul-betul tidak mau lagi untuk menggunakan narkoba.

Menurut penjelasan pasien, orang tua memasukkan mereka karena mereka yakin bahwa pelayanan yang diberikan lembaga ini cukupbaik dandapatmenyembuhkan anaknya dari ketergantungan Narkoba. Selama pasien menerima pelayanan dari lembaga, mereka tahu dan memahami kewajiban yang harus dilakukan selama di lembaga, seperti menaati aturan lembaga, dan mengikuti program sampai dengan batas waktu yang ditentukan.

Pelayanan rehabilitasi sebagai hak yang harus diterima oleh pasien meliputi, pendidikan, makan, minum, pakaian, dan kunjungan dari keluarga. Kepuasan terhadap pelayanan panti rehabilitasi dibuktikan dengan adanya perubahan yang terjadi pada diri pasien, seperti pasien bertambah sehat, pasien mau mengikuti kegiatan kelompok, semangat untuk hidup lebih baik dan mau membaur dengan sesame pasien serta petugas di Yayasan Mutiara Abadi Binjai (MAB).

Perubahan ini tampak dari perbandingan kondisi pasien sebelum dan sesudah mendapatkan pelayanan dari panti. Perubahan ini semua berkat adanya dukungan dari berbagai pihak, seperti petugas administrasi, teknis (pekerja sosial, konselor, dokter), dukungan keluarga, program, kegiatan, peralatan kegiatan, teman penerima program.

Setelah melakukan wawancara tahap selanjutnya adalah mengajak pasien yang sedang rehabilitasi untuk mendengarkan musik yang sudah diaransemen sendiri. 
Tabel 2. Persentase Gerakan Tubuh Ketika Mendengarkan Musik Instrumental

(Sumber: Junita Batubara, 2021)

\begin{tabular}{cccccc}
\hline No & Nama pasien & $\begin{array}{c}\text { Persentase } \\
\text { gerakan } \mathbf{1}\end{array}$ & $\begin{array}{c}\text { Persentase } \\
\text { gerakan } \mathbf{2}\end{array}$ & Rata-rata & $\begin{array}{c}\text { Rata-rata } \\
\text { Gerakan }\end{array}$ \\
\hline 1 & NG & $\mathbf{1 6 , 6} \%$ & $\mathbf{3 0} \%$ & 1 bulan & $\mathbf{2 3 , 3} \mathbf{3}$ \\
\hline 2 & AM & $20 \%$ & $25 \%$ & 2 tahun & $22,5 \%$ \\
\hline 3 & IR & $16,6 \%$ & $25 \%$ & 7 Bulan & $20,8 \%$ \\
\hline 4 & RB & $16,6 \%$ & $20 \%$ & 8 bulan & $18,3 \%$ \\
\hline 5 & LS & $16,6 \%$ & $20 \%$ & 3 bulan & $18,3 \%$ \\
\hline 6 & Har & $\mathbf{1 6 , 6} \%$ & $\mathbf{4 0} \%$ & 8 bulan & $\mathbf{2 8 , 3} \%$ \\
\hline 7 & AH & $13,3 \%$ & $20 \%$ & 2 bulan & $16,65 \%$ \\
\hline 8 & HA & $10 \%$ & $15 \%$ & 1 tahun & $12,5 \%$ \\
\hline
\end{tabular}

Dalam terapi musik, alunan musik dipilih berdasarkan elemen berikut, tempo lagu yang stabil, suasana hati yang tenang,baris melodi yang dapat diprediksi,stabilitas dalam volume, timbre, ritme, harmoni dan nada, struktur sederhana, bentuk yang jelas (Bonny: 2002).

Irama musik yang diaransemen sendiri terdiri atas dua buah musik yang didengarkan oleh pasien. Pada musik yang pertama alunan musiknya dengan tempo lambat mengajak pasien untuk sejenak relaksasi dan membayangkan mereka dalam suasana yang tenang seperti dipagi hari, sedangkan musik yang kedua alunan musik yang girang mengajak pasien untuk tetap senang dan gembira.

Adapun perlakuan yang dilakukan adalah dengan mengamati gerak tubuh setelah mendengar alunan musik yang telah kami buat komposisinya baik dengan tempo cepat maupun tempo lambat. Bahkan, pasien dapat membuat suara musik yang dibangun oleh dirinya sendiri, misalnya tepuk tangan, siulan, hentakkan kaki, jentikan jari, tepuk dada, tepuk paha, dan sebagainya, seperti halnya musik internal yang dibangun oleh pemain itu sendiri (Rustiyanti, 2014: 153). Alunan musik yang kami buat bertujuan untuk mengobati pasien yang sedang menjalani rehabilatasi.

Berdasarkan pengamatan yang dilakukan terdapat 8 responden, di mana respondennya semua laki-laki (100\%) dengan rentang usia dari 27 tahun -51 tahun, lama rehabilitasi yang berbeda-beda mulai 1 bulan-2 tahun serta jenis narkoba yang dipakai terdiri dari ekstasi, ganja dan shabu-shabu. Hasil yang telah dilakukan penelitian dengan mendengarkan music, maka diperoleh Pada musik yang pertama dengan irama (beat) yang lambat diperoleh skor tertinggi sebanyak 6 gerakan dari 30 gerakan yang diperhatikan atau sebesar $20 \%$ pada responden no 2 , alunan musik pertama membawa responden terbawa dalam suasana rileks, baik itu pada pikiran maupun pada tubuh. Sehingga apa yang dirasakan responden dapat meningkatkan daya ingat, membawa mereka mengingat masa lalunya yang begitu indah dan mengingat halhal positif yang mereka lakukan dimasa lalu. Sementara pada alunan musik yang kedua dengan jenis musik dengan irama (beat) yang 
lebih cepat serta alunan musik yang lebih semangat responden no 6 menjadi tertinggi dalam reaksi terhadap tubuhnya sebanyak 8 gerakan dari 20 gerakan yang diperhatikan atau sebesar $40 \%$. Setelah digabungkan dua musik yang berbeda irama (beat), maka hasilnya diperoleh responden no 6 sebesar $28,3 \%$ dan responden no 1 sebesar 23,3\% menjadi responden teraktif dalam gerakan tubuh setelah mendengar musik.

Setelah diamati responden no 1 telah menjalani rehabilitasi selama sebulan sedangkan responden no 6 selama 8 bulan. Dari wawancara yang dilakukan setelah mendengar musik, responden no 1 sangat suka mendengar musik dan suka karokean selama ini. Responden no 1 adalah pasien yang menjalani rehabilitasi pengguna shabu-shabu. Responden no 6 menjalani rehabilitasi selama 8 bulan yang mana sebelum direhabilitasi responden tersebut adalah pengguna ganja. Penggunaan ganja yang berlebihan juga bisa mengganggu kesehatan mental. Misalnya, menyebabkan kambuhnya gejala psikosis pada mereka yang mengidap skizofrenia. Tidak hanya itu, ganja membuat seseorang mengalami halusinasi, delusi, meningkatkan rasa cemas, dan serangan panik. Penggunaan ganja dalam jangka panjang juga membuat seseorang sulit tidur, mengalami perubahan suasana hati, dan berkurangnya nafsu makan.

\section{SIMPULAN}

Pemerintah melalui BNN (Badan Narkotika Nasional) melakukan tindakan melalui terapi rehabilitasi secara ketat dan sistematik dengan menggunakan metode terapi medis dan psikologis, maupun komunitas-komunitas atau organisasi sukarela lainnya yang ingin membantu para pecandu terlepas dari jeratan narkoba. Rehabilitasi bertujuan untuk mewujudkan kepulihan dari ketergantungan narkotika dan mengembalikan keberfungsian sosial pecandu dan korban penyalahgunaan narkotika di masyarakat. Dalam rangka memenuhi kebutuhan masyarakat akan rehabilitasi pecandu dan korban penyalahgunaan narkotika.

Hasil wawancara dengan pasien yang menjadi korban penyalahgunaan Narkoba terungkap bahwa mereka pada masa lalunya menggunakan narkoba disebabkan oleh beberapa hal, seperti depresi akibat masalah keluarga, tekanan pekerjaan, salah pergaulan, maupun rasa penasaran dengan narkoba sehingga mereka dengan nekat mengkonsumsi narkoba semata-mata untuk menenangkan pikiran mereka. Akibat dari perbuatan mereka yang menggunaka narkoba ini menyebabkan rusaknya fisik dan mental mereka. Sebagai upaya penyembuhan dari ketergantungan pihak keluarga melakukan tindakan rehabilitasi dengan datang ke lembaga untuk mendapatkan rehabilitasi, karena mereka ingin sembuh dan betul-betul tidak mau lagi untuk menggunakan narkoba.

Pada penelitian ini, Terapi musik yang dilakukan adalah terapi musik pasif, alasan pemilihan terapi musik pasif karena terapi musik yang murah, mudah dan efektif. Pasien tinggal mendengarkan dan menghayati suatu alunan musik tertentu yang disesuaikan dengan masalahnya, dimana terapi musik tersebut dapat mengurangi rasa sakit, 
membuat fisik dan pikiran menjadi lebih rileks serta manfaat lain disesuaikan dengan muatan isi musiknya. Hal terpenting dalam terapi musik pasif adalah pemilihan jenis musik harus tepat dengan kebutuhan pasien. Penelitian ini diharapkan menjadi salah satu solusi untuk membantu pasien yang sedang rehabilitasi bisa pulih sehingga para pasien ini bisa beraktivitas seperti biasanya.

Hasil dari penelitian yang kami lakukan di Yayasan Mutiara Abadi Binjai, kami mendapatkan respon yang positif serta adanya pengaruh musik terhadap pasien yang sedang menjalani rehabilitasi.

\section{UCAPAN TERIMAKASIH}

Penulis menyampaikan ucapan terimakasih kepada Lembaga Pusat Penelitian dan Pengabdian Masyarakat (LPPM) Universitas HKBP Nommensen yang telah memberikan support dan bantuan dana penelitian. Tak lupa juga kepada tim pencacah data dalam keterlibatan penelitian di lapangan yaitu Fitria Banjarnahor dan Yohana Margaretta Nababan, keduanya adalah mahasiswa Prodi Seni Musik Universitas HKBP Nommensen Medan.

\section{DAFTAR PUSTAKA}

Abimanyu, Bambang. (2017). Gurita Narkoba Di Indonesia. Jakarta: Indonesia press.

Albornoz, Y. (2011). The Effects of Improvisational Music Therapy on Depression in Adolescents and Adult with Substance Abuse: A Randomized Controleed Trial. Nordic Journal of Music Therapy. Vol. 20(3): 208-224.

American Art Therapy Association (AATA). "The History of Art Therapy." Artikel diakses pada 10 Mei 2021 dari http://www. Arttherapyjournal. org/2021/0510/index.html

Argstatter, H. (2016). Perception of basic emotions in music: Culture-specific or multicultural? Psychology of Music, 44 (4), 674-690.

Badan Narkotika Nasional Republik Indonesia. (2019). Laporan kinerja instansi pemerintah badan narkotika nasional tahun 2019. Retrieved from http://bnn.go.id

Bonny H. In: Music \& consciousness. Barcelona Publishers, editor. Barcelona Publisher; Ghilsum, NH: 2002.

Edwards, J . (2017). The Oxford handbook of music therapy. Oxford: Oxford University Press.

Fallek R., Kristen Corey K., Aamna Qamar A., Vernisie S., Hoberman A., Selwyn P., Lounsbury D. Soothing the heart with music: A feasibility study of a bedside music therapy intervention for critically ill patients in an urban hospital setting. Palliative \& Supportive Care. 2019:1-8.

Gouk P. (2000) Musical Healing in Cultural Contexts. Aldershot: Ashgate

Horden P. (2000) Music as Medicine. The History of Music Therapy since Antiquity. Aldershot: Ashgate.

https://www.drugabuse.gov/publications/ principles-drug-addiction-treatmentresearch-based-guide-third-edition/ frequently-asked-questions/howeffective-drug-addiction-treatment

https://wdr.unodc.org/wdr2019/world drug report 2019.

https://www.idntimes.com/news/indonesia/ afrianisusanti/terapi-musikmetodepengobatan-yang-kurang- 
eksis-di-indonesia, diakses tanggal 8 Januari 2019, jam 18. 45 WIB

James Hiller, PHD, MT-BC. (2019) Music Therapists' Preparation for Song Discussion: Meaning - Making With the Music. Music Therapy Perspectives, Volume 37, Issue 2, Fall 2019, Pages 205-212.

Martono, Lydia Harlina dan Satya Joewana. (2005). Modul Latihan Pemulihan Pecandu Narkoba Berbasis Masyarakat Untuk Pembimbing dan Pecandu Narkoba. Jakarta: Balai Pustaka.

Montello, Louise. (2004). Essential Musical Intelligence. Batam: Lucky Publisher.

M. Solihin. (2004) Peneyembuhan Penyakit Kejiwaan Perspektif Tasawuf. Pustaka Setia, Bandung.

Natalina. (2013). Terapi Musik (Bidang Keperawatan). Jakarta: Mitra Wacana Media.

Padila, P., Setiawati, S., Inayah, I., Mediani, H. S., \& Suryaningsih, C. (2020). Emosi dan Hubungan Antar Sebaya pada Anak Tunalaras Usia Sekolah Antara Terapi Musik Klasik (Mozart) dan Murrotal (Surah Ar-Rahman). Jurnal Keperawatan Silampari, 3(2), 725-763.

Puspaningrum, H., Heppy Dwi Rochmawati, Sawab. (2015). Pengaruh Terapi Musik Klasik Mozart Terhadap Kemampuan Mengontrol Halusinasi Pada Pasien Halusinasi Di RSJ Dr. Amino Gondohutomo Provinsi Jawa Tengah. Jurnal Ilmu Keperawatan Dan Kebidanan (Jikk), Vol. 4

Rustiyanti, Sri. (2014). Musik Internal dan Eksternal dalam Kesenian Randai. Resital, Vol. 15 (2), 152-162.

Rustiyanti, Sri, dkk. (2015). Ekspresi dan Gestur Penari Tunggal dalam Budaya Media Visual dua Dimensi. Panggung Vol. 25 (1), 91 - 99.

Saifudin, Moh \& Pandu Wijaya. (2016). Pengaruh Terapi Musik Klasik Terhadap Tingkat Kecemasan Remaja Putra (13-15 Tahun). Jurnal Ners Community. 07(01), $21-32$.

Shofa, Anis Nailus. (2015). Metode Rehabilitasi Jiwa Bagi Pecandu Narkoba di Panti Rehabilitasi Cacat Mental dan Rumah
Sakit Jiwa Nurussalam Sayung Demak Dalam Pandangan Psikoterapi Islam, Skripsi, Universitas Islam Negeri Walisongo, Semarang.

Torres ML, M., Ramos V, J., Suarez PC, M., Garcia S, A., \& Mendoza M, T. (2016). Benefits of Using Music Therapy in Mental Disorders. Journal of Biomusical Engineering, 04(2).

Van der Steen J., Smaling H., van der Wouden J. (2018). Musicbased therapeutic interventions for people with dementia. The Cochrane Database of Systematic Reviews. 2018;7

Christiani, Yuri, Mulyanto \& Adam Wahida. (2021). Terapi Seni di Masa Pandemi Corona Virus Disease-19 (Covid-19). Jurnal Panggung V31/N1/03/2021

Zakiyah Fatmiludya. (2018). Bentuk Terapeutik Dalam Seni Musik Untuk Menanggulangi Pecandu Narkoba Di Perkumpulan Keluarga Kembang Cahaya Purwokerto. Skripsi . Institut Agama Islam Negeri Purwokerto. Purwokerto 